\title{
Correction to: Identifying palliative care needs of patients with non-communicable diseases in Indonesia using the SPICT tool: a descriptive cross-sectional study
}

\author{
Christantie Efendy ${ }^{1,2^{*}}$, Jony Francisco Dos Santos Silva ${ }^{3}$ and Retna Siwi Padmawati ${ }^{2,4,5}$
}

\section{Correction to: BMC Palliat Care 21, 13 (2022)}

https://doi.org/10.1186/s12904-021-00881-5

Following the publication of the original article [1], the last reference provided was not implemented during corrections stage. The last reference as below should have been included.

Jony Francisco Dos Santos Silva. Identifikasi Kebutuhan Palliative Care pada Pasien Penyakit Kronis di Ruang Rawat Inap Dewasa di RSUP Dr. Sardjito Yogyakarta. Thesis. 2020. Yogyakarta. Unpublished

The original article has been updated.

\section{Author details}

${ }^{1}$ Department of Medical Surgical Nursing, Faculty of Medicine, Public Health and Nursing, Universitas Gadjah Mada, Jl. Farmako, Sekip Utara, Depok District, Sleman, Special Region of Yogyakarta, Yogyakarta 55281, Indonesia. ${ }^{2}$ Center for Bioethics and Medical Humanities, Faculty of Medicine, Public Health, and Nursing, Universitas Gadjah Mada, Yogyakarta, Indonesia. ${ }^{3}$ Hospital Nacional Guido Valadares, Dili, Timor-Leste. ${ }^{4}$ Department of Health Behavior, Environment, and Social Medicine; Faculty of Medicine, Public Health, and Nursing, Universitas Gadjah Mada, Yogyakarta, Indonesia. ${ }^{5}$ Graduate Study

Program on Bioethics, Universitas Gadjah Mada, Yogyakarta, Indonesia.

\author{
Reference \\ 1. Effendy C, Silva JFDS, Padmawati RS. Identifying palliative care needs of \\ patients with non-communicable diseases in Indonesia using the SPICT \\ tool: a descriptive cross-sectional study. BMC Palliat Care. 2022;21:13. \\ https://doi.org/10.1186/s12904-021-00881-5.
}

Published online: 05 February 2022

The original article can be found online at https://doi.org/10.1186/s12904021-00881-5.

${ }^{*}$ Correspondence: christantie@ugm.ac.id

${ }^{2}$ Center for Bioethics and Medical Humanities, Faculty of Medicine, Public Health, and Nursing, Universitas Gadjah Mada, Yogyakarta, Indonesia

Full list of author information is available at the end of the article

(c) The Author(s) 2022. Open Access This article is licensed under a Creative Commons Attribution 4.0 International License, which permits use, sharing, adaptation, distribution and reproduction in any medium or format, as long as you give appropriate credit to the original author(s) and the source, provide a link to the Creative Commons licence, and indicate if changes were made. The images or other third party material in this article are included in the article's Creative Commons licence, unless indicated otherwise in a credit line to the material. If material is not included in the article's Creative Commons licence and your intended use is not permitted by statutory regulation or exceeds the permitted use, you will need to obtain permission directly from the copyright holder. To view a copy of this licence, visit http://creativecommons.org/licenses/by/4.0/. The Creative Commons Public Domain Dedication waiver (http://creativeco mmons.org/publicdomain/zero/1.0/) applies to the data made available in this article, unless otherwise stated in a credit line to the data. 